\title{
A sporomorph ecogroup model for the Northwest European Jurassic - Lower Cretaceous II : Application to an exploration well from the Dutch North Sea
}

\author{
O.A. Abbink ${ }^{\star 1}$, J.H.A. Van Konijnenburg-Van Cittert ${ }^{2}$ \\ C.J. Van der Zwan ${ }^{3}$ \& H. Visscher ${ }^{1,2}$

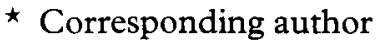 \\ ${ }^{1}$ TNO-NITG, P.O. Box 80015, NL-3508 TA Utrecht, The Netherlands; \\ e-mail: o.abbink@nitg.tno.nl \\ ${ }^{2}$ Laboratory of Palaeobotany and Palynology, Utrecht University, Budapest- \\ laan 4, NL-3584 CD Utrecht, The Netherlands; \\ e-mail: j.h.a.vankonijnenburg@bio.uu.nl, h.visscher@bio.uu.nl \\ ${ }^{3}$ SIEP-SEPTAR, P.O. Box 80, NL-2280 AB Rijswijk, The Netherlands; \\ e-mail: kees.vanderzwan@shell.com
}

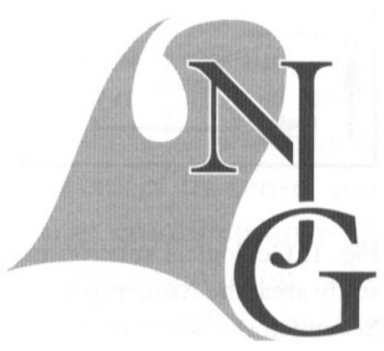

Manuscript received: September 2003; accepted: January 2004

\begin{abstract}
Jurassic shallow marine to non-marine depositional sequences are among the most important economic targets in the North Sea. Detailed, 'high resolution' stratigraphy of these sequences has become a necessity in both predictive geological exploration models as well as in production reservoir models. In these paralic sequences, palynomorphs are the most abundant (micro) fossil group. Palynology is increasingly challenged to improve the biostratigraphic control, and to support the sequence stratigraphical framework. Based on a recently developed, conceptual Sporomorph EcoGroup model, the quantitative distribution patterns of terrestrial palynomorphs are grouped in six Sporomorph EcoGroups (SEGs), viz. Upland, Lowland, River, Pioneer, Coastal, and Tidally-influenced SEG. Application of the SEG model to data from a marginal marine, uppermost Callovian - Middle Oxfordian section of NAM well F17-4 from the southern part of the Central North Sea Graben allows the recognition of sea-level fluctuations and climate changes. A marked palaeoclimatic shift occurred in the earliest Middle Oxfordian. The relatively cool-subtropical, humid climate changed into a warmer, subtropical-tropical, drier climate. The sea-level reconstructions based on the SEG model are validated against a latest Callovian - Earliest Oxfordian depositional sequence.
\end{abstract}

Keywords: palynology, exploration geology, Late Jurassic, sequence stratigraphy, palaeoclimate, sea level.

\section{Introduction}

From an economic viewpoint, the Jurassic contains the most important offshore plays in the North Sea, and a number of these are characterised by paralic deposits (Brown, 1990, Ziegler, 1990). Since the North Sea area is a mature hydrocarbon province, there is an increasing need for biostratigraphic control, characterisation of the depositional environment, and recognition of correlatable horizons in subsurface geology. In particular, a sequence stratigraphic framework may provide support for the identification of the controls and distribution of Jurassic - Early Cretaceous paralic reservoirs (e.g., Partington et al., 1993a and $b$ ). This involves a solid correlation to the (ma- rine) stratigraphical standards, and the recognition and accurate dating of marine floodings. However, in particular in paralic deposits, shallow marine and terrestrial calcareous microfossils are most often absent, while marine palynomorphs (dinoflagellate cysts, acritarchs) are scarce or also absent. In contrast, terrestrial palynomorphs (spores, pollen) are abundant.

It is generally accepted that, notably within terrestrial to marginal marine settings, relative frequency changes within successive sporomorph assemblages predominantly reflect changes in the palaeovegetation rather than differences in transportation, preservation or sedimentation (Muller, 1959; Chaloner \& Muir, 1968; Heusser, 1979; Traverse, 1988; Van Konijnenburg - Van Cittert \& Van der Burgh, 1996; Abbink, 
1998; Abbink et al., 2001). In Quaternary palynology this relationship is successfully applied in the identification of local and regional environmental change. In the Neogene and even in the Paleogene, identification of part of the sporomorph assemblages still enables direct floristic comparisons with extant plant communities and forms a sound basis for the introduction of palaeocommunity models that may enable the environmental interpretation of sporomorph distribution patterns (Poumot, 1989, Van der Zwan \& Brugman, 1999; Van der Zwan, 2002).

For the Mesozoic, based on actualistic principles including plant strategies (see Grime, 1979), one may assume the presence of distinctive habitat-bounded palaeocommunity types, each of which is characterised by taxa with broadly similar ecological preferences. These palaeocommunity types can serve as a palaeoecological framework for a conceptual Sporomorph Ecogroup model of co-existing sources of dispersed spores and pollen. In such a conceptual model, six Sporomorph EcoGroups (SEGs) for the NW European Jurassic - Early Cretaceous may be established, viz. the Upland, Lowland, River, Pioneer, Coastal, and Tidally-influenced SEG (Abbink et al., 2004, see also Fig. 6). Since the type of vegetation reflected by the SEGs is governed by two principal controls, geography and climate (see Abbink et al., 2004) shifts in (1) the relative abundance of SEGs, and (2) the quantitative composition of individual SEGs may be expected to be indicative of changes in geographic setting and/or climate. In this way, the SEG model can be used for the recognition of sea-level fluctuations and climate changes in paralic settings. In this paper, the SEG model is applied to the palynological data from well F17-4 of the Nederlandse Aardolie Maatschappij B.V. (NAM). This well was selected because of its relatively unique palynomorph assemblages (Abbink, 1998). In addition to a high terrestrial influx, the palynomorph assemblages contain a distinctive marine signal that can be used for detailed age-assessment and to further substantiate the palaeoenvironmental interpretations.

\section{Exploration well F17-4}

\section{Material}

NAM well F17-4 has been drilled in June 1982 as an exploration well in the southern part of the Central North Sea Graben, in the offshore of The Netherlands (Fig. 1). The Central Graben acted as one of the main centres of deposition during Late Jurassic and Early Cretaceous times (Ziegler, 1990). In the South Central North Sea Graben (the southernmost

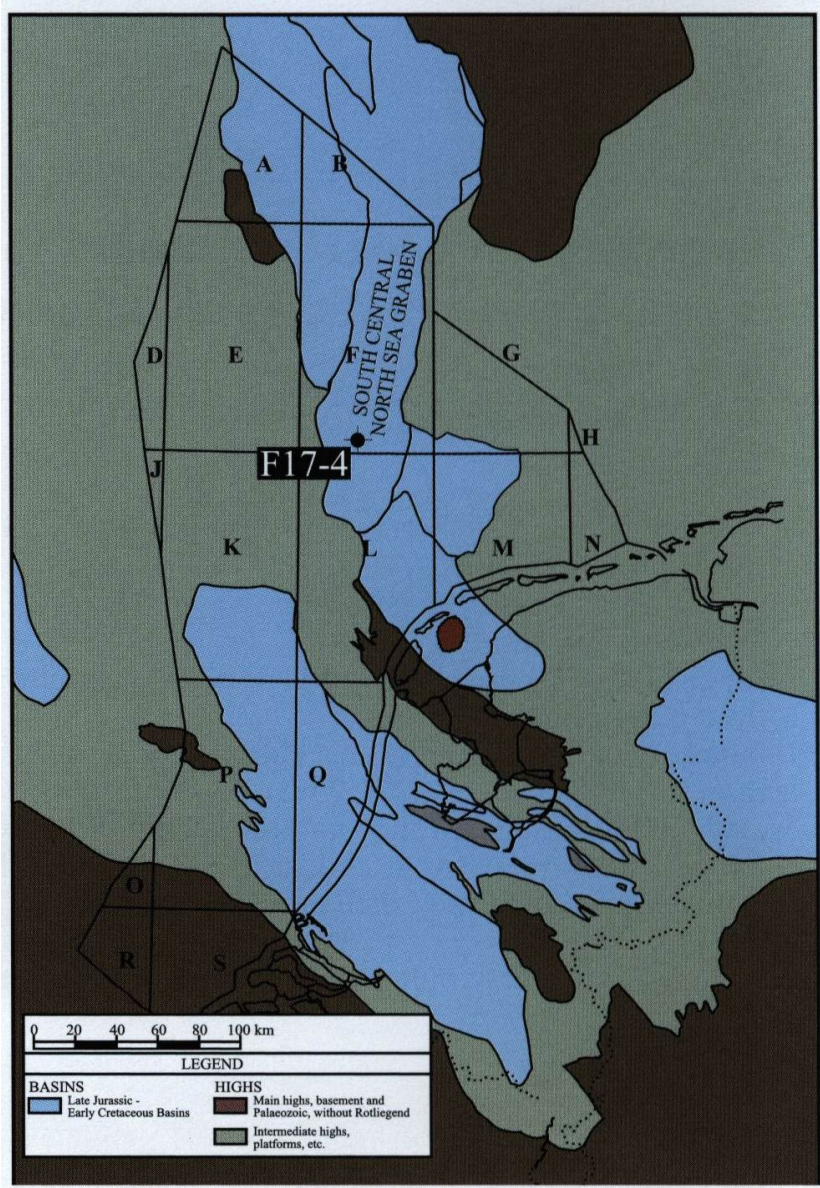

Fig. 1 Simplified representation of the structural outlines of the Late Jurassic basins and location of well F17-4 (slightly modified after unpublished NAM information).

extension of the Central Graben), deposition is considered to have been generally paralic during the Late Jurassic and marine during the Early Cretaceous (Herngreen \& Wong, 1989; Ziegler, 1990; Van Adrichem Boogaert \& Kouwe, 1993). Furthermore, the sedimentary succession was affected by various tectonic events causing breaks in deposition (Ziegler, 1990).

The Upper Jurassic - Lower Cretaceous lithostratigraphic scheme given in Van Adrichem Boogaert and Kouwe (1993) is followed. A simplified well-log of well F17-4 is given in Fig. 2, in which the positions of cuttings samples (sample code CT), side-wall samples (sample code SW) and cored intervals (sample code $\mathrm{CO}$ ), the lithology and lithostratigraphy are indicated. The base and top of the investigated interval of well F17-4 are formed by two distinct unconformities at $2411 \mathrm{~m}$ and at $2572 \mathrm{~m}$ separating the interval from overlying Lower Cretaceous and underlying Lower Jurassic sediments, respectively (Van Adrichem Boogaert \& Kouwe, 1993; Abbink, 1998). 


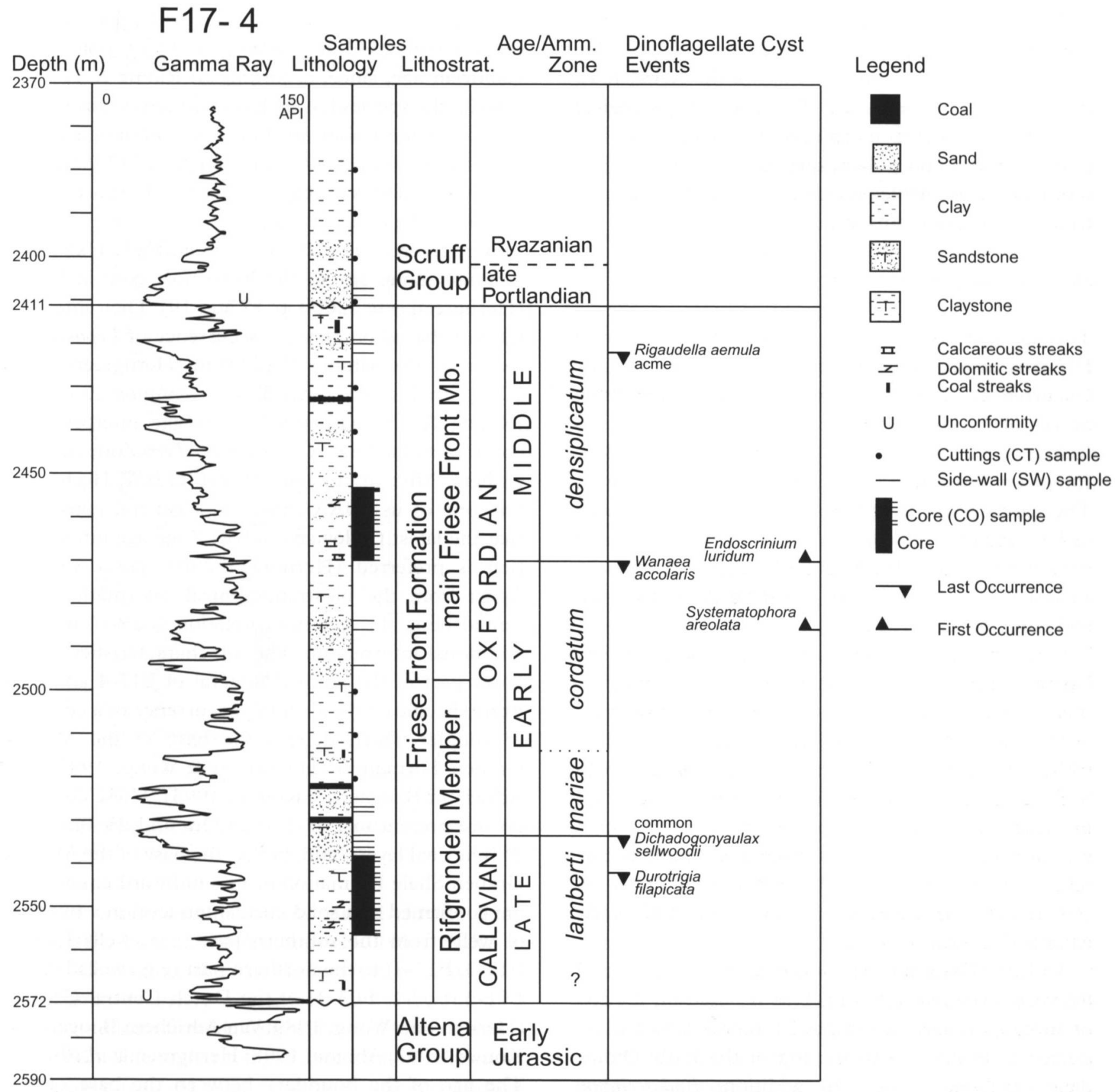

Fig. 2 Compiled well-log of well F17-4 with age-breakdown and important dinocyst events. Well-log legend is after SIEP (1995).

\section{Methods}

\section{Sample processing}

Samples from well F17-4 were processed in the NAM laboratory using palynological standard techniques. All samples were treated with heavy liquid separation $\left(\mathrm{ZnBr}_{2}\right)$ and the sample residues were sieved using a $15 \mu \mathrm{m}$ metal precision sieve. For the slides, glycerine jelly was used as a mounting medium.

\section{Sample analysis}

All samples were analysed qualitatively and quantitatively. The quantitative analysis consisted of two steps.
In the first step, nine categories of palynomorphs, viz., alete bisaccate pollen, spores/pollen (others), acritarchs, organic-walled dinoflagellate cysts (dinocysts), reworked palynomorphs, fresh/brackish water organisms, foram remains, fungal remains and animal remains have been counted up to a total of 100 specimens. The second step consisted of counting separately spores/pollen (except alete bisaccate pollen) and aquatic palynomorphs (dinocysts and fresh/ brackish water organisms) up to 150 specimens of each group, if possible. Consequently, the quantitative important sporomorphs are grouped according to the SEG model. Dinoflagellate cyst taxonomy corre- 
sponds to that cited in Lentin et al. (1998). The sporomorph taxonomy is cited in Abbink (1998). The material is stored in the collection of the NAM B.V., Assen, The Netherlands. The full palynological dataset (major palynomorph groups, quantitative important spores and pollen, qualitative palynology) of well F17-4 is available on request in MS-Excel format from the corresponding author.

\section{Age-assessment of well F17-4}

The age-assessment of the studied interval of well F17-4 is based on First Occurrences (FOs) or Last Occurrences (LOs) of dinocysts. The stratigraphic ranges of the dinocyst given below are according to Riding and Thomas (1992) unless otherwise stated. Important biostratigraphic events are given in Fig. 2 . The age-assessments are based on data from side-wall (SW) samples and core (CO) samples. The Boreal stratigraphy and the Standard Boreal Ammonite Zonation followed here are based on data in Cariou and Hantzpergue (1997).

Rigaudella aemula, present in sample $2422.00 \mathrm{mSW}$, has its LO at the top of the Middle Oxfordian. Furthermore, Partington et al. (1993b) report the presence of an acme of this species at his J52 flooding which falls within the densiplicatum Zone in the North Sea region. Since this species is rare throughout the investigated interval but occurs in relatively high numbers in sample $2422.00 \mathrm{mSW}$, this sample is correlated with the $\mathrm{J} 52$ flooding of Partington et al. (1993b) and, ensuing, the densiplicatum Zone (early Middle Oxfordian).

An Early Oxfordian age is attributed to the interval between $2470 \mathrm{~m}-2528.5 \mathrm{~m}$. This is based on the LO of Wanaea acollaris in sample $2470.00 \mathrm{~m}$ which is reported to coincide with the top of the Early Oxfordian (cordatum Zone). In addition, Endoscrinium luridum of which the FO has been reported from the top of the cordatum Zone has its FO in this sample. Furthermore, the FO of the Systematophora areolata group is in sample $2486.00 \mathrm{mSW}$. This event has been reported from the base of the cordatum Zone. Between the latter sample and sample $2525.00 \mathrm{mSW}$, the side-wall samples are not productive. However, based on the sequence stratigraphic interpretation, the base of the cordatum Zone is correlated to depth $2515 \mathrm{~m}$ (see below).

A Late Callovian age is inferred for the interval between $2533 \mathrm{~m}-2570 \mathrm{~m}$. This age-assessment is based on the common occurrence of Dichadogonyaulax sellwoodii and the LO of Durotrigia filapicata. Various authors have reported Dichadogonyaulax sellwoodii from Oxfordian sediments, but the relatively large numbers encountered in the side-wall and core samples from the interval $2533.00 \mathrm{mSW}-2556.40 \mathrm{~m}$ point to a Callovian age, since, according to Riding \& Thomas (1992), the species has its last common occurrence at the top of the Callovian. This is corroborated by the LO of Durotrigia filapicata in sample $2542.00 \mathrm{~m}$. The LO of this species is generally accepted to correlate to the top of the Late Callovian.

Herngreen et al. (2000) assign an Early Oxfordian cordatum Zone age to the lowermost core in F17-4 (Herngreen et al., 2000, p. 17 and 19). Their interpretation is based on a single occurrence of Leptodinium subtile in core sample $2548.00 \mathrm{~m}$ (Herngreen et al., 2000 , Enclosure 2) which has cordatum Zone FO (Riding \& Thomas, 1992). This age interpretation contradicts the latest Callovian lamberti Zone age given here. After discussion between G.F.W. Herngreen and one of us (OAA), there is a general consensus that the latest Callovian lamberti Zone age interpretation is preferred (Herngreen 2003, pers. comm.). Apart from the biostratigraphical information presented here, this age interpretation is also based on additional information. The log characteristics of the lower part of the studied interval of F17-4 are relatively specific, and reflect the occurrence of a coal layer couplet which defines the base of the Middle Graben Formation (Herngreen \& Wong, 1989; Van Adrichem Boogaert \& Kouwe, 1993). These coal layers are present in F17-4 at $2522 \mathrm{~m}$ and $2530 \mathrm{~m}$ (Fig. 2). The coal layers, and, hence, the base of the Middle Graben Shale Formation or its southward equivalent, are confirmed as a solid correlation level in a number of wells from the southern part (e.g., wells L05-3, F17-3, F17-4) to the northern part (e.g., wells F11-1, F11-2, F03-1, F03-3) of the Dutch Central Graben (Herngreen\& Wong, 1989; Van Adrichem Boogaert \& Kouwe, 1993; Abbink, 1998; Herngreen et al., 2000). The age of the boundary between the base of the Middle Graben Formation and underlying Lower Graben Formation is confidently dated as the boundary between the earliest Oxfordian mariae Zone and the latest Callovian lamberti Zone (Herngreen \& Wong, 1989; Van Adrichem Boogaert \& Kouwe, 1993; Abbink, 1998; Herngreen et al., 2000). Since the studied lower core is directly below this boundary, a latest Callovian lamberti Zone age interpretation is concluded.

\section{Climate}

\section{Callovian - Oxfordian palaeoclimate}

The palaeoclimate of the Northwest European Callovian - Oxfordian is conceived as a warm-tem- 


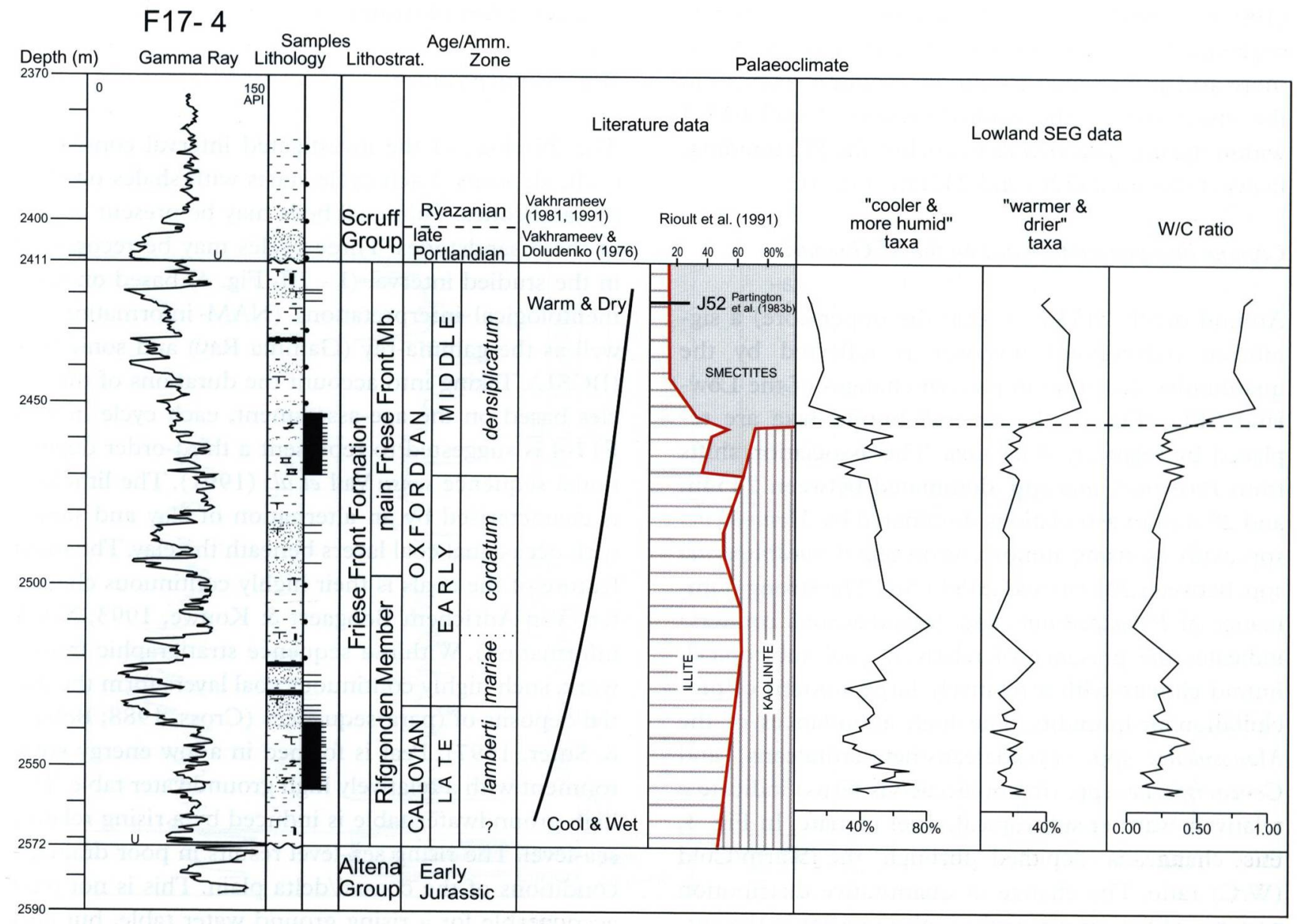

Fig. 3. Literature data and climate curves based on the Lowland SEG. W/C ratio $=$ Warmer sporomorphs versus Cooler sporomorphs of the Lowland SEG. Note that to the right is relatively warmer and drier. See text for further explanation.

perate to subtropical, relatively humid climate (Hallam, 1984, 1985, 1994; Vakhrameev, 1991; Frakes et al., 1992). During the Middle Jurassic, the climate is considered relatively cooler and more humid than that of the Late Jurassic (e.g. Hallam, 1984; Frakes et al., 1992). The higher temperature and, in particular, the aridity reached their peak in Northwest Europe during the Kimmeridgian and Portlandian (e.g. Hallam, 1984; Wignall \& Ruffel, 1990; Ruffel \& Rawson, 1994). The Callovian - Oxfordian mark the change from the Middle Jurassic to the Late Jurassic climate conditions. This change is usually considered gradual (compare Frakes et al., 1992, their Fig. 7.3). However, more detailed analysis suggests a more 'step-wise' change of the climate (Hallam, 1984, 1994; Wignall \& Ruffel, 1990) and within the Callovian - Oxfordian time-interval several phenomena related to such 'steps' are described. One phenomenon was the swift northward progression of coral reefs in the Oxfordian, indicating a significant warming in this period (Arkell, 1956; Hallam, 1994). Furthermore, studies in the former USSR show that there was a rapid, climate-induced floral turnover. Vakhrameev \& Dolu- denko (1976) placed this turnover at the Middle Late Jurassic boundary, i.e. at the Callovian - Oxfordian boundary. In addition, Vakhrameev $(1981,1991)$ reports that the subtropical belt of the former USSR and Asia advanced $15-20^{\circ}$ northward in the Early Middle Oxfordian. However, the fact that all studies imply that this climate change occurred relatively rapid and was significant, suggests that such a climate event is present within the Late Callovian - Middle Oxfordian. Another indicator for this event may be found in the studies of clay minerals by Rioult et al. (1991). The clay mineral curve of Rioult et al. (1991) is depicted in Fig. 3. Within the basal part of the densiplicatum Zone (early Middle Oxfordian), illite and kaolinite are almost totally replaced by smectite.

Although there are several problems surrounding the use of clay minerals as climate indicators (e.g. Hallam et al., 1991), smectite is considered an indicator for a more arid and possibly warmer climate (Ruffel \& Rawson, 1994). The inception of smectite falls within the Calcaire d'Auberville below the maximum flooding surface (MFS) of sequence 150.2, within the basal part of the densiplicatum Zone. Partington et al. 
(1993b) correlate their J52 flooding with the MFS of sequence 150.2 . This means that a climate change to more arid and warmer conditions would be present in the upper part of the studied section of well F17-4 within the densiplicatum Zone, below the J52 flooding, hence, between $2422 \mathrm{~m}$ and $2470 \mathrm{~m}$ (Fig. 3).

\section{Climate interpretations based on the SEG model}

Around depth $2454 \mathrm{~m}$ (within the upper core) a significant palynofloral turnover is reflected by the quantitative distribution pattern changes of the Lowland SEG (Fig. 3). In general, humid taxa are replaced by relatively drier taxa. The association shifts from Perinopollenites spp. dominated between $2454 \mathrm{~m}$ and $2570 \mathrm{~m}$ to associations dominated by Monosulcites spp. with as rising minor constituent Concavisporites spp. between $2411 \mathrm{~m}$ and $2453.65 \mathrm{~m}$. The strong dominance of Perinopollenites spp. (taxodiaceous conifers) indicates the presence of relatively cool subtropical, humid climate with a relatively large amount of precipitation/air-humidity. The high abundances of the Monosulcites spp. (cycadaleans/bennettitaleans) and Concavisporites spp. (matoniaceaeous ferns) indicate a relatively warmer subtropical, drier climate. In Fig. 3, this change is depicted through the Warm/Cold (W/C) ratio. The change in quantitative distribution patterns of the sporomorphs is also present in the cuttings samples $(2430 \mathrm{mCT}, 2440 \mathrm{mCT}$ and $2450 \mathrm{mCT}$; see Fig. 3). It is unlikely that this quantitative data is the result of caving, since the overlying interval (2411 $\mathrm{m}$ and higher) is marine (Abbink, 1998; NAM information). Therefore, these samples are taken into account in Fig. 3. Furthermore, this indicates that palaeoenvironmental changes on such a time-scale are recordable in cuttings samples.

For several reasons, the floral change cannot be ascribed to a local change in the palaeoenvironment only (Abbink et al., 2001). The presumed rise in temperature and the precipitation decrease are unlikely to have been local events. Furthermore, the interpreted palaeoenvironment precludes the lateral existence of different types of lowland forest vegetation. This points to the suggested replacement of the Lowland SEG in time. Finally, this presumed change in palaeoclimate appears to be unrelated to both the lithostratigraphy/sedimentology or to the described cycles/ sequences (compare Figs 3 and 4).

Our data point to a marked palaeoclimatic shift in the earliest Middle Oxfordian (Fig. 3). The relatively temperate subtropical, humid climate changed into a warmer, somewhat drier subtropical climate. This is in accordance with the prediction based on smectite abundances (Abbink et al., 2001).

\section{Sea-level fluctuations}

\section{Well log interpretation}

The lithology of the investigated interval consists of cyclic deposits. Each cycle starts with shales overlain by sandstones. Thin coal beds may be present on top of these sandstones. Three cycles may be recognised in the studied interval (I - III, Fig. 4) based on sedimentological interpretations (NAM information) as well as the gamma-ray (Gamma Ray) and sonic logs (BCSL). Taking into account the durations of the cycles based on the age-assessment, each cycle in well F17-4 is suggested to represent a third-order depositional sequence sensu Vail et al. (1991). The lithology is characterised by an alternation of clay and sands, with occasional coal layers beneath the clay. The main feature of the coals is their highly continuous character (Van Adrichem Boogaert \& Kouwe, 1993; NAM information). Within a sequence stratigraphic framework, such highly continuous coal layers form the initial deposits of (para)sequences (Cross, 1988; Bohacs $\&$ Suter, 1997). Peat is formed in a low energy environment with a relatively high groundwater table. The high groundwater table is induced by a rising relative sea-level. The rising sea-level results in poor drainage conditions of the coastal/delta plain. This is not only accountable for a rising ground water table, but also for a significant drop in river discharge which results in a low sediment supply. The sedimentology of the mudstones indicates at least shallow marine, lagoonal conditions (NAM information). As there is no evidence for severe erosion at the base of these mudstones, the transgression over the coals appears relatively rapid and widespread. According to Bohacs and Suter (1997), the rising sea-level was matched by the rising groundwater table and peat formation for only a limited time. After this point in time, the vegetation drowned and a rapid transgression established marine conditions, resulting in the deposition of (shallow) marine shales. The overlying sands occur at the top of progradational seaward-stepping parasequences (Reinson, 1984, Cross, 1988).

In a sequence stratigraphic framework, the sands correlate to the later part of the Highstand Systems Tract (HST), e.g. Reinson (1984), Cross (1988) \& Loutit et al. (1988). The underlying shales are interpreted as the transgressive systems tract (TST) and early HST (e.g. Posamentier \& Vail, 1988, Vail et al., 1991). The base of each cycle corresponds to a sequence boundary (SB) and is formed by the base of the coal layers or the base of the shale. The maximum flooding surface (MFS) is developed within the clay deposits. The sequence stratigraphic breakdown 


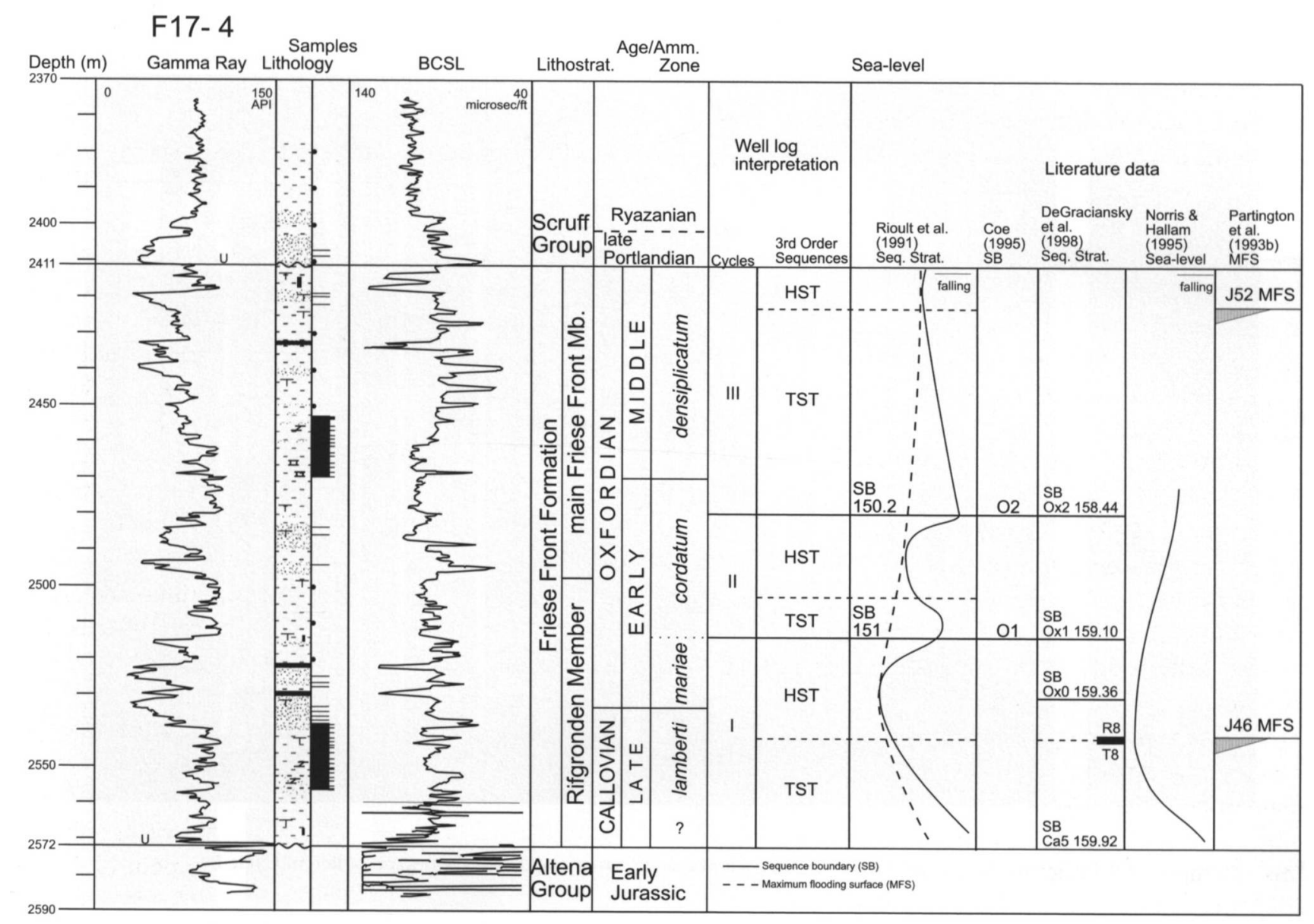

Fig. 4. Cycles and sequence stratigraphic breakdown of well F17-4 based on well data, and the sea-level data on literature.

based on well data is depicted in Fig. 4.

\section{Correlation with literature data}

In recent years, the rise of sequence stratigraphy has inspired the study of Jurassic sea-level fluctuations. After the publication by Haq et al. (1988) several studies were conducted concerning the sea-level fluctuations of the Callovian - Oxfordian in Northwest Europe. Partington et al. (1993a, b) defined and calibrated maximum flooding surfaces across the North Sea basin. Rioult et al. (1991), De Graciansky et al. (1998) and Jacquin et al. (1998) revised the Haq et al. (1988) curve. The Oxfordian sequence stratigraphy for the southern and western parts of the UK was studied by Coe (1995). The studies of Rioult et al. (1991), Coe (1995), and Jacquin et al. (1998) show that there are two sequence boundaries present in the investigated, Late Callovian - early Middle Oxfordian, interval. The SB 151 of Rioult et al. (1991), SB O1 of Coe (1995), and SB Ox1 of Jacquin et al. (1998), which are placed at the base of the cordatum Zone (Early Oxfordian) correspond to the base of our Cycle II, at depth $2515 \mathrm{~m}$. Consequently, the age of the base of our Cycle II correlates to the base of the cordatum Zone (Early Oxfordian). The base of our Cycle III, at depth $2480 \mathrm{~m}$, corresponds to SB 150.2 of Rioult et al. (1991), SB O2 of Coe (1995), and SB Ox2 of Jacquin et al. (1998). The SB Ox0 of Jacquin et al. (1998) may be present in the earliest Oxfordian mariae Zone of our studied interval. However, this part of the section appears to comprised to positively confirm this.

Based on the age interpretation and the acme of Rigaudella aemula, the MFS of Cycle III is suggested to correlate to the J52 MFS of Partington et al., 1993b (see paragraph Age-assessment of well F17-4). Of marked importance is the study of Norris \& Hallam (1995). They emphasised the global sea-level maximum of the latest Callovian (lamberti Zone) which correlates to the MFS of sequence 153 of Rioult et al. (1991), J46 flooding of Partington et al. (1993b), and to the Peak Transgression of T/R 8 of Jacquin et al. (1998). This flooding is distinctly present within our data and corresponds to the MFS of Cycle I, around depth $2542 \mathrm{~m}$ (Fig. 4). Moreover, the palaeoenvironmental data from wells from the Dutch Central Graben show that the marine flooding pre- 


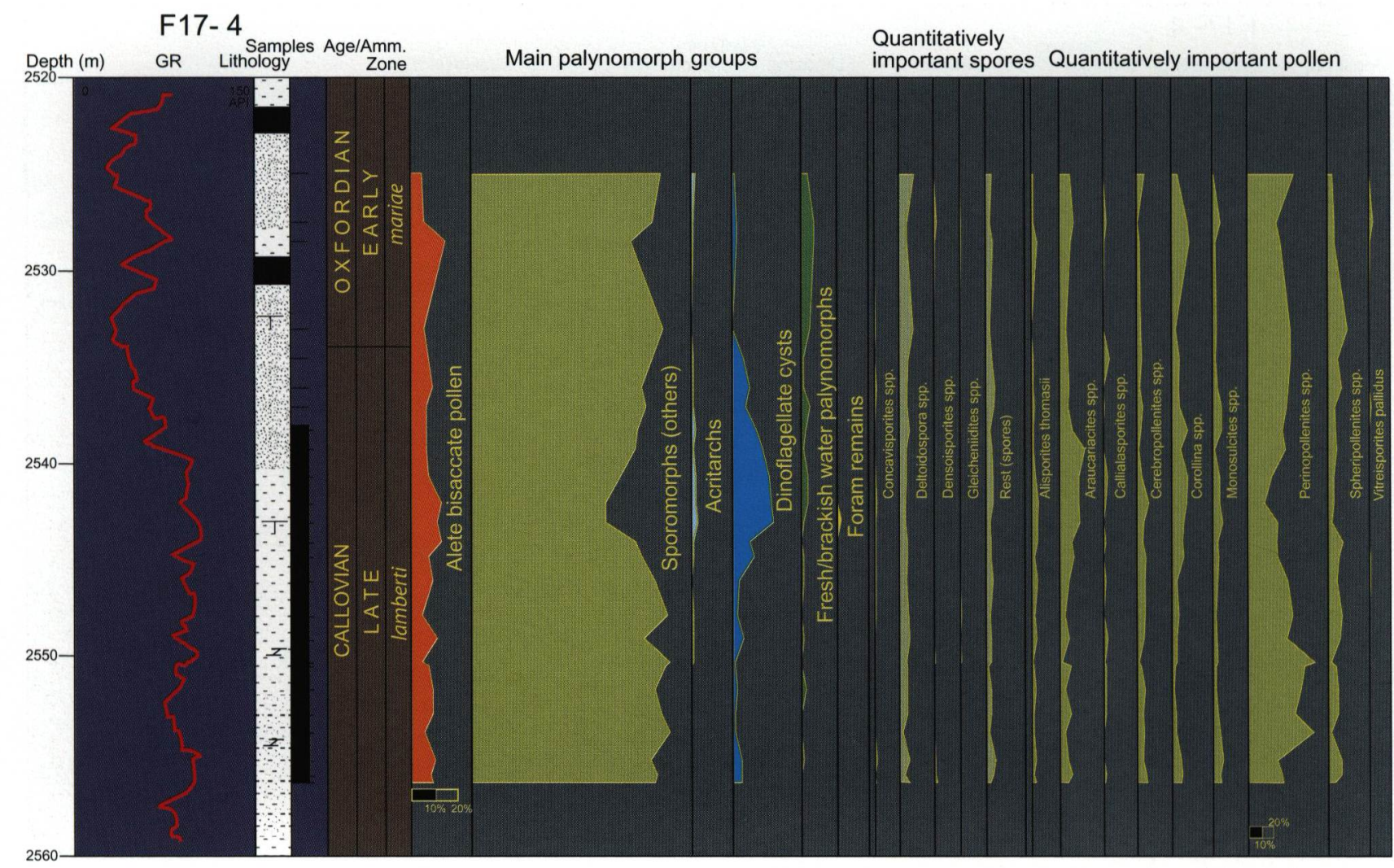

Fig. 5. Relative abundances of the major palynomorph groups, and quantitatively important spores and pollen of Cycle I.

sent around $2542 \mathrm{~m}$ (Fig. 4) is correlative with a major flooding level in the Dutch Central Graben (Van Adrichem Boogaert \& Kouwe, 1993; Abbink, 1998; Herngreen et al., 2000). The exact stratigraphic position of this global flooding, if synchronous, appears to show subtle differences which may be due to the biostratigraphic resolution (compare e.g., Partington et al.; 1993b, Coe, 1995, Norris \& Hallam, 1995; Gygi et al., 1998).

\section{Recognition of sea-level fluctuations based on the SEG model}

The relationship between the sedimentology and quantitative palynomorph distribution patterns from well F17-4 has been examined in detail. Cuttings (CT) samples are considered unreliable due to inherent downhole caving and are, therefore, not considered. In terms of sample density, Cycle I is best represented. Consequently, the quantitative palynological data from interval $2525 \mathrm{~m}-2556.4 \mathrm{~m}$, which coincide with the main part of Cycle I, are evaluated and compared with the non-palynological data in detail.

In establishing the palaeoenvironmental reconstruction on the basis of palynology, two phases of interpretation have been undertaken. The first phase considers the distribution patterns of the seven main categories of palynomorphs (alete bisaccate pollen, sporomorphs (others), acritarchs, dinocysts, reworked palynomorphs, fresh/brackish water palynomorphs and foram remains). In the second phase, the quantitatively important spores and pollen are separately grouped according to the SEG model. The sporomorph taxon Spheripollenites is not taken into account in view of its ambiguous botanical affinity. Reworked Carboniferous - Early Jurassic sporomorphs are present throughout the whole interval. However, since these occur in very low numbers, they have been left out of further considerations.

The palynological assemblages of Cycle I are dominated by the category sporomorphs (others). In turn this category is dominated by Perinopollenites spp. (see Fig. 5). The dinocyst category shows an upward increase followed by a decrease, indicating an overall transgressive-regressive trend (Fig. 5). The highest relative abundance of dinocysts occurs in sample $2543 \mathrm{~m}$. Furthermore, fresh/brackish water palynomorphs (Tasmanites and Botryococcus) are present above $2542 \mathrm{~m}$ in relatively higher numbers, corroborating the inferred regressive trend in this interval (Fig. 5). Foram remains are present in sample $2543.00 \mathrm{~m}$, also indicating marine conditions. The abundance of the acritarchs, dinocysts and foram remains (marine organisms) versus sporomorphs (oth- 


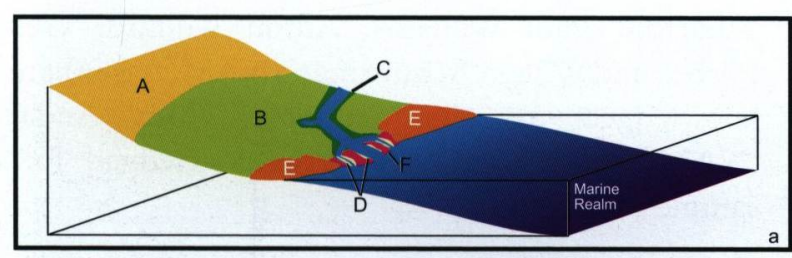

F17- 4

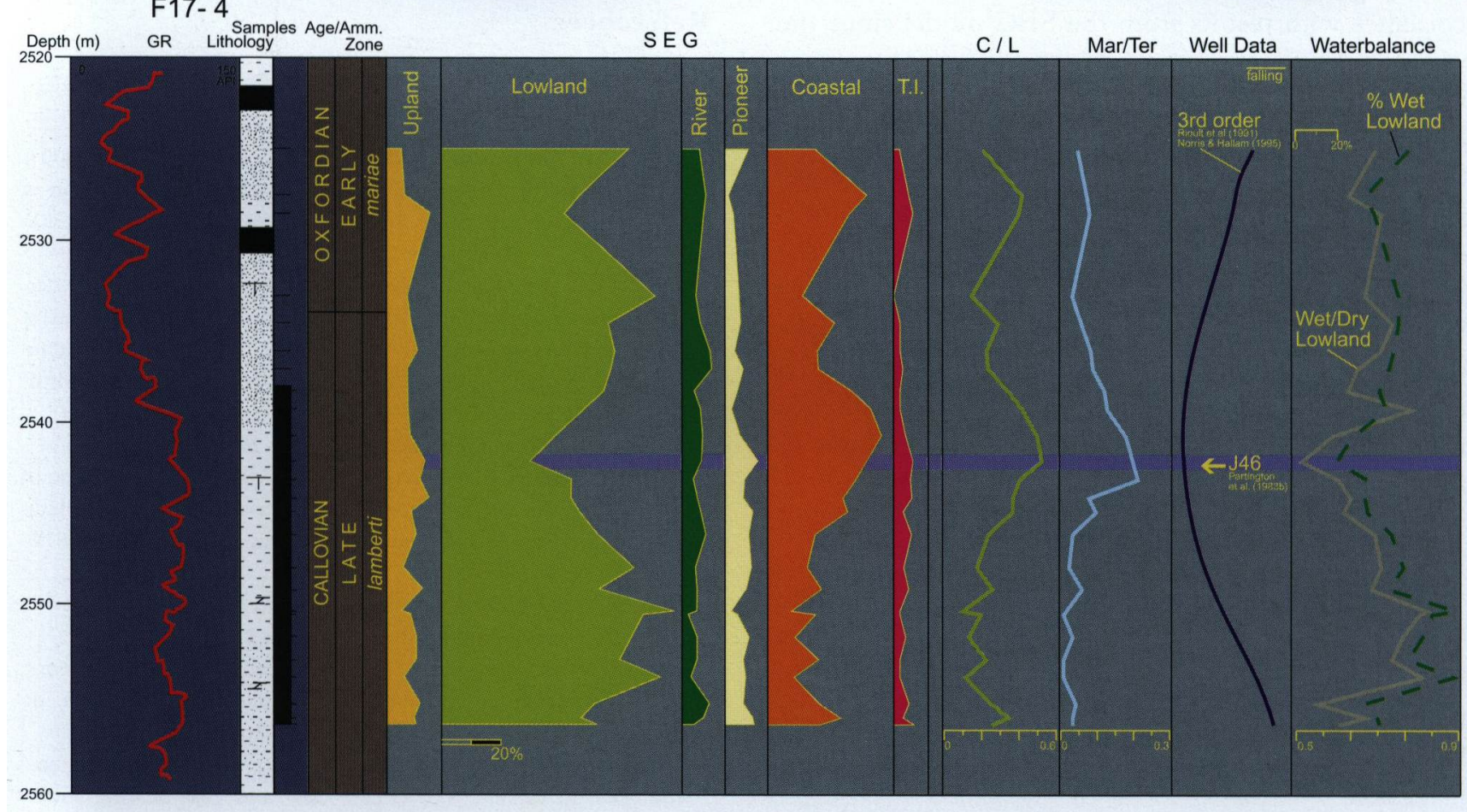

Fig. 6. Relative abundances of the SEGs, the Mar/Ter ratio and Coastal/Lowland (C/L) ratio and waterbalance indicators of Cycle I and distribution of the SEGs during sea-level high (left) and sea-level low (right). $\mathrm{A}=$ Upland, B = Lowland, $\mathrm{C}=$ River, $\mathrm{D}=\mathrm{Pioneer}, \mathrm{E}=\mathrm{Coastal}$ and $\mathrm{F}=$ Tidally-influenced SEG. See text for further explanation.

ers) is expressed in the Marine/Terrestrial (Mar/Ter) ratio (Fig. 6). This ratio may be regarded as a proxy for the relative sea-level and varies between 0 (= nonmarine) and 0.2 (= most marine). The results of the $\mathrm{Mar} / \mathrm{Ter}$ ratio support the interpretation of a sea-level maximum (or MFS) around $2542 \mathrm{~m}$.

Superficially, the selected quantitatively important spores and pollen do not show any distinct trend (Fig. 5). However, if these taxa are grouped according to the SEG model (See Abbink et al. 2004, their Table 2 ), the distribution patterns of the SEG show explicit trends (Fig. 6).

There is an overall upward decrease of the Lowland SEG towards sample $2542 \mathrm{~m}$ succeeded by an upward increase. The Coastal SEG has its highest abundance around samples $2540.60 \mathrm{~m}$ and $2527.50 \mathrm{mSW}$ and a smaller spike in sample $2556.00 \mathrm{~m}$. In addition, the highest abundances of the Upland SEG and the Tidally-influenced SEG occur around samples $2542.00 \mathrm{~m}$ and $2528.50 \mathrm{~m}$. The abundance of the Coastal SEG in relation to the Lowland SEG is represented in the Coastal/Lowland (C/L) ratio (Fig. 6). This ratio may also be considered to represent a

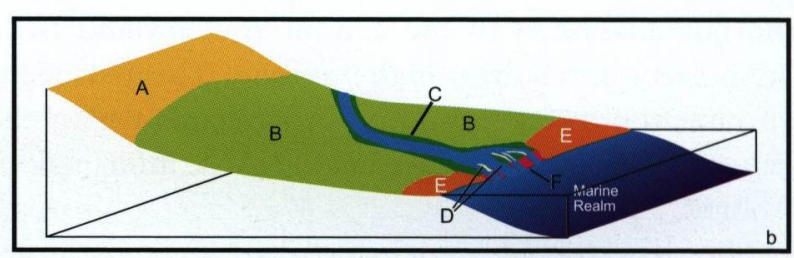

Mar/Ter Well Data Waterbalance

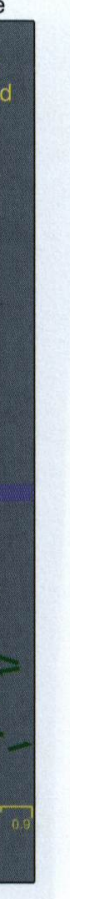


morphs attributed to the coastal and lowland SEG are present in relatively high numbers. This palaeoenvironmental interpretation is in agreement with the general sedimentological data (NAM information; Abbink, 1998).

The depositional model described above is in accordance with results from the SEG model since the well $\log$ interpretations and literature data compare very well to the sea-level interpretations based on palynology (see Fig. 6). The highest Mar/Ter ratio at $2542 \mathrm{~m}$ corresponds to the MFS of sequence I (compare Figs 4 and 6). The Upland and the Tidally-influenced SEG have their maximum at the MFS, and the Coastal SEG slightly above. The Lowland SEG has its minimum at the MFS. The $\mathrm{C} / \mathrm{L}$ ratio has its highest value slightly above the MFS and is, therefore, a proxy for the MFS. The overall results stress the potential of our conceptual SEG model as a tool to recognise sea-level changes in paralic environments.

\section{Conclusions}

The application of the conceptual SEG model shows that the interpretation of quantitative distribution patterns of Jurassic sporomorph assemblages allows the reconstruction of palaeoenvironmental changes, in particular sea-level fluctuations and climate changes. Climate changes are reflected by significant shifts within the SEGs, especially within the Lowland SEG. Variations between the various SEGs permit the identification of sea-level fluctuations. The ratio between the Coastal and Lowland SEGs is a proxy for the MFS. The palynological expression of a SB or parasequence boundary in a paralic setting correlates with a sharp increase in 'wetter' elements within the Lowland SEG.

The SEG model allows the recognition depositional sequences, including maximum flooding surfaces, in Jurassic - Early Cretaceous shallow marine to even non-marine settings, exclusively on the basis of palynology.

\section{Acknowledgements}

The Nederlande Aardolie Maatschappij B.V. (Assen) is gratefully acknowledged for their material and financial material and financial sponsorship. TNONITG (Utrecht), the Laboratory of Palaeobotany and Palynology (Utrecht University) and the LPP foundation are gratefully acknowledged for additional material and financial support. Furthermore, we wish to thank Henk Brinkhuis, Waldemar Herngreen and Michiel van Houte (Utrecht University) for their comments and discussions. Peter Oriaifo, Mark
Wharton, Paul Williams, Anton Wolfard, Gordon Forbes and Willem Schuurman (NAM, Assen) are acknowledged for their support. Eddy Anderson (NAM, Assen) is gratefully acknowledged for the sample preparation.

\section{References}

Abbink, O.A., 1998. Palynological investigations in the Jurassic of the North Sea region. LPP Contribution Series 8: $192 \mathrm{pp}$.

Abbink, O.A., Targarona, J., Brinkhuis, H. \& Visscher, H., 2001. Late Jurassic to earliest Cretaceous palaeoclimatic evolution of the Southern North Sea. Global and Planetary Change 30: 231 256.

Abbink, O.A., Van Konijnenburg-Van Cittert, J.H.A. \& Visscher, H., 2004. A Sporomorph Ecogroup Model for the Northwest European Jurassic - Lower Cretaeous I - Concepts and framework. Netherlands Journal of Geociences / Geologie en Mijnbouw 83, 1: 389-404.

Arkell, 1956. Jurassic Geology of the world, Edinburgh: $806 \mathrm{pp}$.

Bohacs, K. \& Suter, J., 1997. Sequence stratigraphic distribution of coaly rocks, fundamental controls and paralic examples. Bulletin of the American Association of Petroleum Geologists: 81: 16121639.

Brown, S., 1990. Jurassic. In: Glennie, K.W. (Ed.). Introduction to the Petroleum Geology of the North Sea: 219-254.

Cariou, E. \& Hantzpergue, P., 1997. Biostratigraphie du Jurassique Ouest-Européen et Méditerranéen, Bulletin des Centres de Recherches Exploration-Production Elf-Aquitaine, 17:440 pp.

Chaloner, W.G. \& Muir, M., 1968. Spores and Floras. In: Murchison, D. and Westall, T.S. (Eds). Coal and coal bearing strata. Oliver and Boyd, Edinburgh: 127-146.

Coe, L. A., 1995 A comparison of the Oxfordian successions of Dorset, Oxfordshire, and Yorkshire. In: Taylor, P.D. (Ed.), Field Geology of the British Jurassic. Geological Society, London: 151-172.

Cross, T., 1988. Controls on coal distribution in transgressive-regressive cycles, Upper Cretaceous. In: Wilgus, C. K., Hastings, B. S., et al. (Eds). Sea Level Changes; An Integrated Approach. Special Publication of the Society of Economists, Paleontologists and Mineralogists, 4: 371-380.

DeGraciansky, P.-C., Hardenbol, J., Jacquin, T., Vail, P.R. \& Farley, M.B., 1999. Jurassic sequence chronostratigraphy/ biochronostratigraphy. In: De Graciansky et al. (Eds), Mesozoic-Cenozoic Sequence Stratigraphy of European Basins. Special Publication of the Society of Economists, Paleontologists and Mineralogists 60: Charts 6 and 7 .

Frakes, L.A., Francis, J.E. \& Syktus, J.I., 1992. Climate Modes of the Phanerozoic, Cambridge University Press: 274 pp.

Grime, J. P., 1979. Plant Strategies \& Vegetation Processes, Sheffield: $222 \mathrm{pp}$.

Gygi, R.A., Coe, A.L \& Vail, P.R., 1999. Sequence stratigraphy of the Oxfordian and Kimmeridgian stages (Late Jurassic) in Northern Switzerland. In: De Graciansky et al. (Eds), MesozoicCenozoic Sequence Stratigraphy of European Basins. Special Publication of the Society of Economists, Paleontologists and Mineralogists, 60: 527-544.

Hallam, A., 1984. Continental humid and arid zones during the Jurassic and Cretaceous. Palaeogeography, Palaeoclimatology, Palaeoecology 47: 195-223.

Hallam, A., 1985 A review of Mesozoic climates. Journal of the Geological Society of London, 142: 433-445.

Hallam, A., 1994. Jurassic climates as inferred from the sedimenta- 
ry and fossil record. In: Allen, J.R.L., Hoskins, B.J., Sellwood, B.W., Spicer, R.A. \& Valdes P.J. (Eds), Palaeoclimates and their Modelling. The Royal Society, Chapman, London: 79-88.

Hallam, A., Grose, J. A. \& Ruffell, A. H., 1991. Palaeoclimatic significance of changes in clay mineralogy across the Jurassic-Cretaceous boundary in England and France. Palaeogeography, Palaeoclimatology, Palaeoecology, 81: 173-187.

Haq, B.U., Hardenbol, J., \& Vail, P.R., 1988. Mesozoic and Cenozoic chronostratigraphy and cycles of sea level change. In: Wilgus, C. K., Hastings, B. S., et al. (Eds), Sea Level Changes; An Integrated Approach. Special Publication of the Society of Economists, Paleontologists and Mineralogists, 42: 71-108.

Herngreen, G.F.W., Kerstholt, S.J. \& Munsterman, D.K., 2000. Callovian-Ryazanian ('upper Jurassic') palynostratigraphy of the Central North Sea Graben and Vlieland Basin, the Netherlands. Mededelingen Nederlands Instituut voor Toegepaste Geowetenschappen TNO 63: 1-99.

Herngreen, G.F.W. \& Wong, Th.E., 1989. Revision of the 'Late Jurassic' stratigraphy of the Dutch Central North Sea Graben. Geologie en Mijnbouw 68: 73-105.

Heusser, L., 1979. Spores and pollen in the marine realm. In: Haq, B.U. and Boersma, A. (Eds). Introduction to marine micropalaeontology. Elsevier, New York: 327-339.

Jacquin, T., Dardeau, G., Durlet, C., DeGraciansky, P.-C. \& Hantzpergue, P., 1999. The North Sea cycle: an overview of $2^{\text {nd }}$ order Transgressive/Regressive facies cycles in Western Europe. In: De Graciansky et al. (Eds), Mesozoic-Cenozoic Sequence Stratigraphy of European Basins. Special Publication of the Society of Economists, Paleontologists and Mineralogists, 60: 445466.

Lentin, J.K., Williams, G.L. \& Fensome, R.A., 1998. Fossil Dinoflagellates; Index to Genera and Species, 1998 Edition. American Association of Stratigraphic Palynologists Contribution Series $25: 817 \mathrm{pp}$.

Loutit, T.S., Hardenbol, J., Vail, P.R. \& Baum, G.R., 1988. Condensed sections: the key to age dating and correlation of continental margin sequences. In: Wilgus, C. K., Hastings, B. S., et al. (Eds), Sea Level Changes; An Integrated Approach. Special Publication of the Society of Economists, Paleontologists and Mineralogists 42: 183-216.

Muller, J., 1959. Palynology of recent Orinoco delta and shelf sediments, reports of the Orinoco Shelf expedition, Vol. 5. Micropalaeontology 5: 1-32.

Norris, M. S. \& Hallam, A., 1995. Facies variations across the Middle-Upper Jurassic boundary in Western Europe and the relationship to sea-level changes. Palaeogeography, Palaeoclimatology, Palaeoecology 116: 189-245.

Partington, M.A.P., Mitchener, B.C., Milton, N.J. \& Fraser, A.J., 1993a. Genetic sequence stratigraphy for the North Sea Late Jurassic and Early Cretaceous of the North Sea: distribution and prediction of Kimmeridgian-Late Ryazanian reservoirs in the North Sea and adjacent areas. In: Parker, J.R., (Ed.), Petroleum Geology of Northwest Europe, Proceedings of the 4th Conference: $347-370$.

Partington, M.A.P., Copestake, P., Mitchener, B.C. \& Underhill, J.R., 1993b. Biostratigraphic correlation of genetic stratigraphic sequences in the Jurassic - lowermost Cretaceous (Hettangian Ryazanian) of the North Sea and adjacent areas. In: Parker, J.R., (Ed.), Petroleum Geology of Northwest Europe: Proceedings of the 4th Conference: 371-386.

Posamentier, H.W. \& Vail, P.R., 1988. Eustatic controls on clastic deposition II - Sequence and systems tract models. In: Wilgus, C. K. \& Hastings, B. S., (Eds). Sea Level Changes; An Integrated Approach. Special Publication of the Society of Economists, Paleontologists and Mineralogists 42: 125-154.
Poumot, C., 1989. Palynological evidence for eustatic events in the tropical Neogene. Bulletin des Centres de Recherches Exploration-Production Elf-Aquitaine 13: 437-453.

Reinson, G.E., 1984. Barrier-islands and associated strand plain systems. In: Walker, R.G. (Ed.), Facies Models. Geological Association of Canada, Toronto: 119-140.

Riding, J.B. \& Thomas, J.E., 1992. Dinoflagellate cysts of the Jurassic System. In: Powell, A.J. (Ed.), A Stratigraphic Index of Dinoflagellate Cysts: 7-98.

Rioult, M, Dugué, O., Jan du Chêne, R., Ponsot, C., Fily, G., Moron, J. \& Vail, P. R., 1991. Outcrop Sequence stratigraphy of the Anglo-Paris basin Middle to Upper Jurassic (Normandy, Maine, Dorset). Bulletin des Centres de Recherches Exploration-Production Elf-Aquitaine 15: 101-194.

Ruffel, A. H. \& Rawson, P. F., 1994. Palaeoclimate control on sequence stratigraphic patterns in the late Jurassic to mid-Cretaceous, with a case study from Eastern England. Palaeogeography, Palaeoclimatology, Palaeoecolog, 110: 43-54.

Traverse, A., 1988. Palaeopalynology, Unwin Hyman, Boston: 600 pp.

Vail, P.R., Audemard, F., Bowman, S.A., Eisner, P.N. \& PerezCruz, C., 1991. The stratigraphic signatures of tectonics eustacy and sedimentology - an overview. In: Einsele, G., et al. (Eds), Cycles and events in stratigraphy: 250-275.

Vakhrameev, V. A., 1981. Pollen Classopolis: indicator of Jurassic and Cretaceous climates. The Palaeobotanis, 28-29: 301-307.

Vakhrameev, V.A., 1991. Jurassic and Cretaceous floras and climates of the Earth. Cambridge University Press, Cambridge: $318 \mathrm{pp}$.

Vakhrameev, V. A. \& Doludenko, M. P., 1976. The Middle-Late Jurassic boundary, an important threshold in the development of climate and vegetation of the Northern Hemisphere. International Geology Review 9: 621-632.

Van Adrichem Boogaert, H.A. \& Kouwe, W.L.F.P., 1993. Stratigraphic nomenclature of the Netherlands, revision and update by RGD and NOGEPA. Mededelingen Rijks Geologische Dienst Nieuwe Serie 50.

Van der Zwan, C.J., 2002. The impact of Milankovitch-scale climatic forcing on sediment supply. Sedimentary Geolog, 147: 271-294.

Van der Zwan, C.J. \& Brugman W.A., 1999. Biosignals from the EA Field, Nigeria. In: Jones, R.W. \& Simmons, M.D. (Eds). Biosignals in production and development geology. Geological Society Special Publication 152: 291-301.

Van Konijnenburg - Van Cittert, J.H.A., \& Van der Burgh, J., 1996. Review of the Kimmeridgian flora of Sutherland, Scotland, with reference to the ecology and in situ pollen and spores. Proceedings of the Geologist's Association 107: 97-105.

Wignall, P. B. \& Ruffel, A. H., 1990. The influence of sudden climatic change on marine deposition in the Kimmeridgian of Northwest Europe. Journal of the Geological Society London 147: 365-371.

Ziegler, P.A., 1990. Geological atlas of Western and Central Europe (2nd edition). Shell International Exploration and Production B.V.The Hague. (The Hague): $238 \mathrm{pp}$. 